\title{
The University of São Paulo on the 2017's GreenMetric Ranking
}

\author{
Patricia Faga Iglecias Lemos*, Fernanda da Rocha Brando, Paulo Almeida, Roberta Consentino Kronka Mülfarth, \\ Tamara Maria Gomes Aprilanti, Luis Otávio do Amaral Marques, Nayara Luciana Jorge and Tadeu Fabrício Malheiros
}

Superintendence of Environmental Management, University of São Paulo, SP, Brazil

\begin{abstract}
The University of São Paulo is a public University and the largest in Brazil. It is broadly organized into distinct campuses that are installed in different cities of the state of São Paulo, each one with its specific aspects. There are more than 95 thousand undergraduate and graduate regularly enrolled students, standing out as one of the best universities in Brazil and Latin America [2]. The performance of the University of São Paulo at the "UI GreenMetric World University Ranking" has improved considerably in 2017 ( $28^{\text {th }}$ position) on the general ranking. The sustainability management process for USP is carried out considering the strengths each campus presents, but the USP governance process ensures standards and good practices are applied similarly to all areas under the university responsibility. As for example, the recent approval of the USP Environmental Policy, which process engaged the whole USP community, working together to understand the complex context of all campuses, what resulted at the end in very innovative arrangements for researching, teaching and practice for sustainability. Different of the past rankings, data provided for GreenMetric 2017 Ranking contemplated USP as a whole, because it is not possible to assess the university environmental sustainability performance in parts. This approach allowed showing the different enhanced efforts of the University as a whole. In addition, the USP's environmental policy-making process brought about more integration between the campuses and effective actions were put into practice, helping to consolidate USP as a sustainable university. The highlight in the score was "Setting and Infrastructure": there are $76.4 \mathrm{~km}^{2}$ of total area and only $2.6 \%$ from them are built-up. The University has been prioritizing the protection of green areas and biodiversity, in São Paulo city campus, totally surrounded by urban environment, but also in the other campuses in the countryside, some of them located in rural environment. This shows that USP's campuses are environmentally responsible, providing students and staff with enjoyable, healthy and in close touch with nature places. On the topic "Transportation", the University of São Paulo stands out also. Incentives to improve choice for public transportation and biking within the university community are among the constant concern of the University of São Paulo, which will be keeping up efforts for that.
\end{abstract}

\section{Introduction}

One of the main concerns of the generations living in the 21 st century is called sustainable development. This term refers to the aim to meet the current society needs without damaging the wellbeing of future generations and ecosystems resilience. For that, it is essential that attitudes and policies in the social, economic and environmental spheres be implemented not only by the people in their daily lives, but also by institutions and companies.

In this context, it is important that each institution of higher education act in order to encourage their students, researches and employees to acquire and maintain sustainable behavior in their routines. An effective way to bring them up to this is by adopting exemplary and effective policies and practices that contribute to the environment and society.

One way to measure and provide transparency to the universities' efforts in this regard is through sustainability reports and rankings. This evaluation and classification, based on sustainable criteria, serves as an incentive for more specific analysis of the aspects in which it needs to get better as well as the maintenance of the current policies in their strengths aspects. In addition to that, the comparison between many universities around the world can result in successful actions being implemented in different countries and thus achieve greater range and efficiency in terms of sustainability.

The UI GreenMetric Ranking is an international ranking that annually shows the sustainability and environmental management efforts of higher education institutions around the world. In its eighth edition, 619 universities from 75 countries located on 5 continents were evaluated. The results can be seen by country, by region, by campus setting and overall.

In this context, this paper aims at presenting some of the good practices University of São Paulo has been put to work in the last years. 


\section{The sustainability in the context of the University of São Paulo}

\subsection{Description}

The University of São Paulo is an international academic community that is broadly organized into 12 distinct campuses installed in 7 different cities of the state of São Paulo. Five of them operate in city of São Paulo and the other campuses operate in 6 other localities in Brazil, each one with its own specific aspects and colleges. The University has 2 more units on the coast (Santos and Ubatuba cities), where studies about marine biology and petroleum engineering are developed.

The total area of USP is about $76.40 \mathrm{~km}^{2}$ and its builtup area is about $1.99 \mathrm{~km}^{2}$. In 2017 there were almost 59 thousand undergraduate students enrolled in the 309 available courses; 37 thousand postgraduate students enrolled in the 265 available programs; 6 thousand faculty members and 16 thousand technical and administrative staff [1].

The University of São Paulo was responsible in 2016 for $13 \%$ of the total brazilian $\mathrm{PhD}$ students. Besides that, 77,813 Masters and 50,388 $\mathrm{PhD}$ have been awarded since the university was founded.

\subsection{USP's performance in 2017}

The University of São Paulo reached the 28th place overall, and the first among the Brazilian Universities in the 2017 GreenMetric Ranking. The highlight was in "Setting and Infrastructure": only $2.6 \%$ of its total area are built-up $\left(1.99 \mathrm{~km}^{2}\right)$. In addition, it also stood out in the themes "Energy and Climate Change", "Water" and "Transport", in which the University of São Paulo reached the six first places of the 64 participating universities from Latin America.

The combined efforts of the entire university community as well as the integrated approach of its several campuses were responsible for this good standing. Besides that, the current process of formulating USP's environmental policies brought more integration between campuses and effective actions were put into practice, helping to consolidate USP as a University that has Sustainability as its goal. In 2012, the Superintendence of Environmental Management - SGA was launched as a USP's agency responsible for the environmental and sustainability institutional relations of the University with federal, state and municipal public institutions $[6,10]$.

\subsection{USP's environmental policy}

In order to promote the integrated environmental management and aiming to guide and legitimize the environmental actions of the University of São Paulo, the University Environmental Policy Working Group was launched in 2014, pushing the process of the USP's Environmental Policy. Their main modus operandi included interdisciplinary approach, transparency, participation and respect for local specificities [7]. The USP's Environmental Policy was enacted in January 2018 and covers 11 themes such as: water and effluents, land use, sustainable buildings, energy, green areas and ecological reserves, mobility, greenhouse gases emission, fauna, administration, solid waste and environmental education [8]. The policy also provides a basis for the formulation of the Environmental Management Plan, and the Environmental Master Plans.

USP's Environmental Policy was elaborated in three main phases: the first, the thematic environmental policies were defined for all university campuses, each one with its different aspects. In this stage 150 volunteers (teachers, technicians and students) were involved, divided into several working groups. In the second (the current one), the environmental management plans are being drawn up with goals and indicators, with the engagement of 170 volunteers from the USP community. The third aims at the Environmental Master Plans to be developed for each of the campuses [9].

\subsection{The USP recycling program}

The USP Recycling Program (USP Recicla) is the oldest and main program, and targets Environmental Education and Waste Management. The program's principles are participation, belonging, empowerment, autonomy, environmental technologies and the 3Rs principle: reduction, reuse and recycling [5]. This program is responsible for the USP sustainability culture index improvement.

USP has a Disposal and Reuse Center for Electronic Waste (CEDIR), which redistributes part of the equipment that can still be used by assistance entities, through a loan. The remaining is disassembled, and its parts are separated and sent to recyclers [13]. There is also the Recicl@tesc Program, in São Carlos campus, launched in 2009, whose objective is the environmentally correct disposing of electronic waste [14].

\subsection{USP infrastructure}

Most of the campuses of the University of São Paulo are located in urban areas and the main campus (in São Paulo City) has the largest built-up area (almost 2 billions $\mathrm{m}^{2}$ ). The largest total areas belong to the Piracicaba Campus (49\%), followed by the Pirassununga Campus (31\%), which are incrusted in urban areas, but kept as rural campuses.

\subsubsection{Green areas}

The University of São Paulo established 2,312 ha of its total area as Ecological Reserves, aiming the conservation, restoration, research, teaching and extension. Most of these natural reserves are fragments of semideciduous forests and tropical savanna [12]. It is important to highlight the importance of the green areas in the USP campuses in the city of São Paulo, once today this city has a significant deficit of vegetation [11]. 


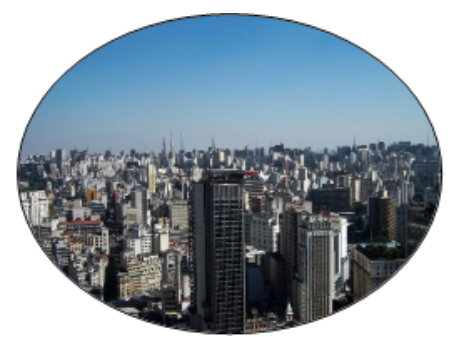

Fig. 1. City of São Paulo Source: Tadeu Malheiros

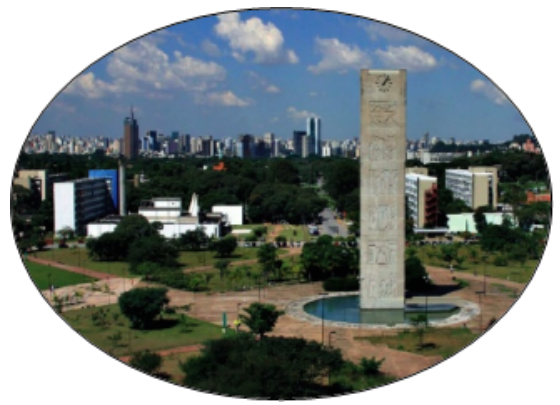

Fig. 2.. Green areas of USP - Campus Cidade Universitária São Paulo.

\subsubsection{Sustainable buildings and energy}

The University has invested in its lighting system, which now uses high-tech LED luminaire HP3, solar panels with excellent performance even in cloudy weather, with an autonomy from 1 day to 3 nights and the intelligent remote management system. The system of remote control of lighting consists of monitoring the points by means of communication antennas installed in each of them, which will transmit, through a georeferencing software, data regarding consumption and operation, that will allow the monitoring of the network at a distance, to control operation, to program drives and lighting levels by location or time.

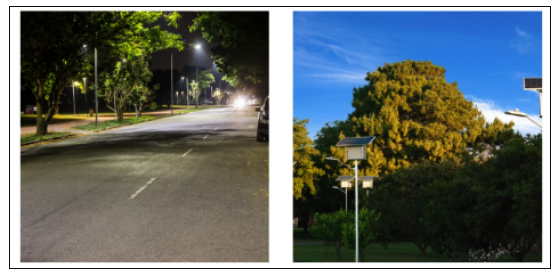

Fig. 3. High-tech luminaire system

The system also provided a reduction of more than $30 \%$ in electricity consumption, even with almost double luminaires (from 3,200 to 6,113 units) [4], since USP's total energy consumption between October 2016 and September 2017 was $61,068 \mathrm{MWh}$, which represents a lower consumption compared to the previous months.

\subsubsection{Mobility}

There are 50 available free shuttle buses operating at the University campuses and more than 5,000 bicycles transiting at USP daily. The campuses located at the city of São Paulo have easy access with bus and subway. The other campuses are mostly accessed by walking distances for the local students [3].

\section{Concluding remarks}

The management of a university with the size of the University of São Paulo is certainly a challenge, as it requires developing governance mechanisms that encompass teaching, research, and extension issues. The sustainable development movement of the second half of the last century brought new and urgent responsibilities for alignment with the principles of sustainability. USP was an active part of this movement, both inside and outside Brazil, and has progressively incorporated the culture of sustainability into its DNA. From speech to practice, today USP invests in a campus that dialogues with its community, with its open doors policy in the cities where it is installed is a key actor and contributes to opening opportunities to society. The environmental issue occupies a prominent place on its campuses, where biodiversity protection and significant amount of green areas contribute to local and global quality of life. Its environmental policy, built on a participatory basis, incorporates and translates its degree of maturity and commitment to the Sustainable Development Goals.

\section{References}

1. USP - Universidade de São Paulo, Anuário Estatístico USP. São Paulo, Brazil (2016)

2. USP, Relatório de Gestão: Uma Universidade em Evolução | 2014-2017, São Paulo, Brazil (2017)

3. Superintendência de Gestão Ambiental, Iniciativas Ambientais na USP (2018) Disponível em: $<$ http://www.sga.usp.br/acoes-da-sga/>. Acesso em 02/2018.

4. Alper Energia, USP. Disponível (2016) em: $<$ http://www.alper.com.br/project/usp/>. Acesso em $02 / 2018$.

5. USP, Portaria GR N $\mathrm{N}^{\mathrm{0}} 5438$, de 22 de dezembro de 2011, São Paulo, Brazil (2011)

6. Superintendência de Gestão Ambiental, Áreas verdes e reservas ecológicas (2018) Disponível em: $<$ http://www.sga.usp.br/grupos-de-trabalho-dasga/politica-ambiental-na-universidade/>. Acesso em 02/2018.

7. Superintendência de Gestão Ambiental, Política Ambiental na Universidade (2018) Disponível em: $<$ http://www.sga.usp.br/grupos-de-trabalho-dasga/politica-ambiental-na-universidade/>. Acesso em 02/2018.

8. USP, 2018. Relatório de Gestão (2014-2017). São Paulo, Brazil.

9. USP, Environmental Policy University of São Paulo: Sustainability Masterplan for Policies, Plans, Goals and Actions. São Paulo, Brazil (2016) 
10. USP, Resolução $n^{\circ}$ 6062, de 27 de fevereiro de 2012 (2012)

11. Prefeitura do Município de São Paulo, "Atlas Ambinetal" do Município de são Paulo: Fase I: Diagnóstico e Bases para a Definição de Políticas Públicas para as Áreas Verdes no Município de São Paulo. São Paulo, Brazil (2002)

12. Superintendência de Gestão Ambiental, Reservas Ecológicas da USP (2018) Disponível em: < http://www.sga.usp.br/acoes-da-sga/reservasecologicas-da-usp/>. Acesso em 02/2018.
13. USP, Projeto Recicl@tesc coleta lixo eletrônico (2012) Disponível em: $<$ http://www.saocarlos.usp.br/index.php?option=co $\mathrm{m} \_$content\&task=view\&id=9529\&Itemid $=171>$. Acesso em 02/2018.

14. USP, Cedir da Esalq recebe descarte de informática da população (2013) Disponível em: < http://www5.usp.br/26894/cedir-da-esalq-recebedescarte-de-informatica-da-populacao/>. Acesso em $02 / 2018$. 